\title{
Intracolony variability in photosynthesis by corals is affected by water flow: role of oxygen flux
}

\author{
C. M. Finelli ${ }^{1,4, *}$, B. S. Helmuth ${ }^{2}$, N. D. Pentcheff ${ }^{3}$, D. S. Wethey ${ }^{2}$ \\ ${ }^{1}$ Louisiana Universities Marine Consortium, 8124 Highway 56, Chauvin, Louisiana 70344, USA \\ ${ }^{2}$ Department of Biological Sciences and Marine Science Program, University of South Carolina, Columbia, \\ South Carolina 29208, USA \\ ${ }^{3}$ Crustacea Section, Natural History Museum of Los Angeles County, 900 Exposition Blvd., Los Angeles, California 90007, USA \\ ${ }^{4}$ Present address: Department of Biology and Marine Biology, University of North Carolina Wilmington, 601 S. College Rd., \\ Dobo Hall 102, Wilmington, North Carolina 28403, USA
}

\begin{abstract}
We provide evidence from field experiments that within-coral colony variation in lightlimited electron transport rates through Photosystem II is positively correlated with water flow over the coral surface. We made in situ paired measurements of water flow and photosynthetic electron transport rates (rETR) over the upstream and downstream faces of several coral colonies at Conch Reef, Key Largo, Florida, USA. Using pulse amplitude modulated (PAM) fluorometry, we estimated rETR at increasing levels of photosynthetically active radiation (PAR). The rETR versus PAR relationship was fitted to a negative exponential curve parameterized by the initial slope $(\alpha)$ and the asymptotic maximum ( $\mathrm{rETR}_{\max }$ ). We showed that flow speeds measured at $3 \mathrm{~mm}$ above the upstream faces of multiple branching colonies of Porites porites and hemispherical colonies of Siderastrea siderea were more than double those over the downstream faces. In both $P$. porites and $S$. siderea, these higher upstream flow speeds were associated with $\alpha$ values that were 4 and $12 \%$ higher, respectively, than those over the downstream faces. In contrast, there were no differences in flow speed, or in $\alpha$ between the upstream and downstream faces of plate-like colonies of Montastrea annularis. Ancillary measurements of oxygen concentrations over intact coral colonies in the field demonstrated that oxygen concentrations within $2 \mathrm{~mm}$ of the coral surface were between 2 to $110 \%$ higher than ambient (measured $>1 \mathrm{~m}$ from the coral). Moreover, paired measurements over a single colony of $S$. siderea showed steeper velocity gradients over the upstream face relative to the downstream face, accompanied by lower oxygen concentrations, a thinner diffusion boundary layer, and higher $\alpha$. Our results support the hypothesis that within-colony variation in photosynthesis by corals is related to water flow, and suggests that oxygen flux from the coral may be important.
\end{abstract}

KEY WORDS: Coral · Water flow · Diffusion boundary layer · Photosynthetic efficiency · PAM fluorometry

Resale or republication not permitted without written consent of the publisher

\section{INTRODUCTION}

Water flow has wide ranging effects on coral reef organisms, especially with respect to the transport of vital nutrients and removal of wastes from sessile organisms. The rate of solute transport into or out of coral tissue scales with the concentration gradient between the tissue and overlying seawater and with the thickness of the diffusive boundary layer (DBL) that characterizes the distances over which molecular diffusion by Brownian motion occur (Shashar et al. 1996). Oftentimes, the DBL is considered a barrier to the uptake of inorganic nutrients (Patterson et al. 1991, Atkinson \& Bilger 1992, Lesser et al. 1994, Thomas \& Atkinson 1997, Gardella \& Edmunds 2001, Nakamura \& van Woesik 2001, Falter et al. 2004). It can, however, also act as a barrier to the release of metabolic wastes and photosynthetically derived oxygen (both molecu- 
lar $\mathrm{O}_{2}$ and oxygen radicals) (Gardella \& Edmunds 1999, Gardella \& Edmunds 2001, Nakamura \& van Woesik 2001, Nakamura et al. 2003, Falter et al. 2004). In this manner, water flow has the potential to modulate photosynthesis of coral symbionts via control of tissue oxygen concentrations. For example, excess oxygen in coral tissues can lead to both direct toxicity (via reactive oxygen species) and a physiological switch from photosynthesis to photorespiration (Lesser 1996, 1997, 2006, Asada 1999, Downs et al. 2002, Tchernov et al. 2004). Recent studies have also hypothesized that spatial patterns of coral bleaching and subsequent recovery are related to water flow over the reef, especially via modulation of oxidative stress (Lesser et al. 1994, Lesser 1997, Nakamura \& van Woesik 2001, Nakamura et al. 2003).

In previous field experiments, we showed that photosynthetic efficiency of colonies of Agaricia agaricites exposed to ambient oxygen concentrations was higher in flow than in no-flow conditions (Finelli et al. 2006). This trend was reversed, however, when the coral was experimentally exposed to elevated oxygen concentrations. That is, under hyperoxic conditions, when the gradient between the coral tissue and the environment was eliminated, the photosynthetic efficiency of zooxanthellae was lower in flow than in no-flow conditions. We concluded that under normal, ambient oxygen concentrations, flow facilitates the removal of photosynthetically-derived oxygen from the coral tissue and the DBL. Under experimentally elevated ambient oxygen concentrations, the oxygen gradient between the coral and surrounding seawater was reversed and oxygen was able to build up within the DBL and coral tissue, modeling an extreme case of the situation under no-flow conditions. This resulted in a depression of photosynthetic efficiency (Finelli et al. 2006).

In the present paper we report the results of a series of field studies showing that intracolony variation in photosynthetic electron transport rates is related to water flow within the momentum boundary layer (MBL). We also demonstrate that oxygen concentrations adjacent to coral tissues under field conditions can be elevated by as much as $110 \%$, and in at least one case, within colony variation in flow correlated with both oxygen concentration and light limited photosynthesis. In aggregate, these findings potentially explain patterns of intracolony bleaching reported in the field that previously have been attributed only to differences in levels of light and/or differences in zooxanthellar genotype. While our results do not contradict the importance of these other mechanisms, they do point to the potential importance of flow and to the coupled effect of colony morphology on mass flux in driving intracolony patterns of bleaching and colony mortality.

\section{MATERIALS AND METHODS}

Study location. We conducted our field studies at a depth of 15 to $20 \mathrm{~m}$ at Conch Reef, located $15 \mathrm{~km}$ south of Key Largo, Florida, USA $\left(24.95018^{\circ} \mathrm{N}, 80.45453^{\circ} \mathrm{W}\right)$. Conch Reef comprises spur and groove coral formations with a crest at about $10 \mathrm{~m}$ and shallow slope extending to a depth of $35 \mathrm{~m}$, before falling off into deeper water (Leichter et al. 2003). Recent field surveys (2002 to 2003) of benthic communities on Conch Reef show that coral cover at 10 to $30 \mathrm{~m}$ depths is generally less than $10 \%$, with at least half of the bottom covered with epilithic macroalgae (D.W. Swanson unpubl. data). These conditions match our observations made at the time of these studies and those of Aronson et al. (1994). Our primary experiments were conducted during a $10 \mathrm{~d}$ mission aboard the Aquarius Undersea Habitat (National Undersea Research Center, University of North Carolina-Wilmington, USA) in October 2000. During the study period, photosynthetically active radiation varied between 0 (at night) and 300 (solar noon) $\mu \mathrm{mol}$ photons $\mathrm{m}^{-2} \mathrm{~s}^{-1}$. Additional oxygen profiles were collected in November 2002 during a separate surface-based research trip. All data were collected in the field by divers using SCUBA.

Flow measurements. We measured flow speed above corals using a heated bead thermistor flow meter with a $2 \mathrm{~mm}$ diameter sensor (LaBarbera \& Vogel 1976). The flow meter was temperaturecompensated daily following the procedures of LaBarbera \& Vogel (1976). In addition, we calibrated the sensor each day by moving it at known rates through a still water bath and regressing the output voltage against speed measured by a linear velocity transducer (e.g. Finelli 2000). Output voltages from the flow meter were recorded at $10 \mathrm{~Hz}$ using a Campbell Scientific CR10X datalogger. Data were collected while the probe was held stationary at a predetermined height (usually $3 \mathrm{~mm}$ ) above the coral for $2 \mathrm{~min}$. Means and standard deviations of calibrated flow speed were calculated for each 2 min period.

PAM fluorometry. We used a pulse amplitude modulated fluorometer (DIVING-PAM, Heinz-Walz) to measure photosynthetic activity with a rapid light curve (RLC) technique. The $6 \mathrm{~mm}$ diameter fiber optic probe was held $5 \mathrm{~mm}$ above the coral surface for all measurements. The PAM fluorometer works by measuring chlorophyll fluorescence under ambient light conditions $(F)$, subjecting the plant to a saturating pulse of actinic light, and re-measuring fluorescence $\left(F_{\mathrm{m}}{ }^{\prime}\right)$. The ratiometric difference in size of these 2 fluorescence signals, $\left(F_{\mathrm{m}}{ }^{\prime}-F\right) / F_{\mathrm{m}}{ }^{\prime}=$ Effective Quantum Yield, $\phi_{\mathrm{p}}$, is proportional to the amount of incident radiation that can be used to drive photosynthesis. During the RLC, corals were exposed to 8 incremental steps of 
photon irradiance ranging from 0 to $350 \mu \mathrm{mol}$ photons $\mathrm{m}^{-2} \mathrm{~s}^{-1}$ for $10 \mathrm{~s}$, after which a measurement of quantum yield $\left(\phi_{p}\right)$ was made. Following Ralph et al. (2002), we used the relative electron transport rate (rETR) through photosystem II as the response variable of interest in our studies: $\mathrm{rETR}=\phi_{\mathrm{p}} \times \mathrm{PAR}$, where PAR is the photon irradiance at each step. rETR is considered a valid proxy for photosynthetic rate in low to intermediate irradiances (Longstaff et al. 2002). Each RLC was then fit to a negative exponential curve of the form:

$$
\mathrm{rETR}=\mathrm{rETR}_{\max } \times\left(1-\mathrm{e}^{\left(-\alpha \times \mathrm{PAR}_{\mathrm{rETR}} \max \right)}\right)
$$

(Platt et al. 1980, Ralph et al. 2002), where rETR $_{\max }$ is the asymptotic photosynthetic rate (i.e. light saturated photosynthetic rate) and $\alpha$ is the slope of the initial linear portion of the RLC. Curve fitting was accomplished using an iterative, least-squares method (NLIN procedure, SAS Institute).

Oxygen profiles. We measured oxygen concentration profiles within $10 \mathrm{~mm}$ of the surface of corals using a fiber optic oxygen sensor with a $300 \mu \mathrm{m}$ tip (FOXY, Ocean Optics). The sensor tip was coated with black RTV silicone to exclude interference from ambient light or reflective surfaces. The oxygen probe was calibrated in the Aquarius Habitat at ambient pressure (depth $\approx 15 \mathrm{~m}$ ) before and after each dive using a $100 \%$ air saturated solution (air bubbled seawater) and an anoxic solution ( $6 \mathrm{ml}$ bakers' yeast, $15 \mathrm{ml}$ honey, $300 \mathrm{ml}$ seawater). Voltage output from the oxygen sensor was recorded using Campbell Scientific CR10X data loggers. Oxygen concentration profiles were collected by holding the sensor at a predetermined height above the coral for $3 \mathrm{~min}$. The sensor was positioned over the coral using a diver-operated micromanipulator with a precision of $2.5 \mu \mathrm{m}$. Due to the slow response of the oxygen sensor, we used only data collected during the final $1 \mathrm{~min}$ of each $3 \mathrm{~min}$ run. The mean and standard deviation of measured oxygen concentration were calculated for each sample period. In addition to profiles, periodic in-water calibration checks were conducted using the anoxic solution (carried to the site by divers) and ambient seawater ( $>1 \mathrm{~m}$ from the seafloor). Because oxygen flux from the coral scales with the gradient between the coral tissue and water column, all oxygen readings were scaled to ambient oxygen concentration $(100 \%)$ measured on site.

Studies. Our primary experiment consisted of paired measurements of flow speed (measured at $3 \mathrm{~mm}$ above the coral) and rETR on the upstream and downstream faces of several small colonies of Montastrea annularis (flat plate morphology), Porites porites (branching morphology), and Siderastrea siderea (hemispherical morphology). The maximum dimension of all corals used was approximately 100 $\mathrm{mm}$. Measurements were made on unperturbed corals on the reef and on corals that had been transplanted to a linear rack located in a sand channel adjacent to the Aquarius Habitat site. The rack was placed in an open spot perpendicular to dominant tidal flow, so that all corals were exposed to similar light and flow conditions. Corals were transplanted $>2$ wk prior to measurements. There was no discernable difference in measurements between the natural and transplanted corals, so data for each species were pooled. Because of the relatively small coral population available within our working area (restricted by the length of power/data cables from the Aquarius Habitat), 1 colony of $M$. annularis, 1 colony of $P$. porites, and 2 colonies of $S$. siderea were sampled twice using the PAM fluorometer; however, at least $1 \mathrm{~d}$ elapsed between measurements. Based on our previous work showing elevated photosynthetic efficiency in flow versus no-flow conditions, and an expectation of higher flow on the upstream side of the coral, we used a one-tailed paired $t$-test (Zar $1984)$ to test the null hypothesis that the difference in flow or photosynthetic parameters $\left(\alpha, \mathrm{rETR}_{\max }\right)$ was $\leq 0$. To further explore the relationship between water flow and photosynthesis at the population level, we calculated Pearson's Correlation Coefficients for (1) $\alpha$ versus flow speed and (2) rETR $_{\max }$ versus flow speed for each species.

In a single instance, we were able to completely characterize the DBL, MBL, and RLC over a colony of Siderastrea siderea (100 $\mathrm{mm}$ hemisphere). Oxygen profiles, flow profiles, and RLCs were collected on the upstream and downstream faces of a small colony of S. siderea.

Oxygen profiles were collected over 5 corals during our studies in 2000 and 2002. In 2000, 4 profiles were collected over 2 different colonies of Siderastrea siderea. Two profiles were collected on the upstream side of a single coral on 2 different dives, while the remaining 2 profiles were collected as upstreamdownstream sets. We were prevented from collecting more profiles in 2000 due to the time-consuming nature of these measurements and by sensor malfunction. In 2002, 3 profiles were collected over the center portion of 3 different colonies of Agaricia agaricites (maximum dimension $150 \mathrm{~mm}$ ). In 2002, we focused on A. agaricites for a separate set of experiments (Finelli et al. 2006) and include the profiles here for comparative purposes only.

\section{RESULTS}

The results of our primary experiments demonstrate a link between water flow and light-limited photosynthesis (Table 1, Fig 1). In Porites porites (branch- 
Table 1. Results of paired upstream and downstream measurements of flow speed $(u)$, initial slope of the rapid light curve $(\alpha)$, and the asymptotic maximum of the rapid light curve $\left(\mathrm{rETR}_{\mathrm{max}}\right)$. Data reported as mean $\pm \mathrm{SD}$. $\mathrm{t}$-values and associated $\mathrm{p}$ values test for single tailed $\mathrm{H}_{0}$ : difference between upstream and downstream measurements $\leq 0$

\begin{tabular}{|c|c|c|c|c|c|c|c|}
\hline Parameter & Species & Upstream & Downstream & $\begin{array}{l}\text { Difference } \\
\text { (Up -Down) }\end{array}$ & $\mathrm{N}$ & $\mathrm{t}$ & $\mathrm{p}$ \\
\hline Flow speed $(\mathrm{u})$ & $\begin{array}{l}\text { Montastrea annularis } \\
\text { Porites porites } \\
\text { Siderastrea siderea }\end{array}$ & $\begin{array}{l}3.8 \pm 1.6 \\
4.2 \pm 2.3 \\
5.0 \pm 2.7\end{array}$ & $\begin{array}{l}3.1 \pm 3.7 \\
1.3 \pm 1.9 \\
2.4 \pm 2.8\end{array}$ & $\begin{array}{l}0.7 \pm 2.4 \\
2.9 \pm 2.4 \\
2.6 \pm 1.5\end{array}$ & $\begin{array}{l}4 \\
5 \\
5\end{array}$ & $\begin{array}{l}0.56 \\
2.71 \\
4.01\end{array}$ & $\begin{array}{l}0.31 \\
0.03 \\
0.01\end{array}$ \\
\hline Initial slope $(\alpha)$ & $\begin{array}{l}\text { Montastrea annularis } \\
\text { Porites porites } \\
\text { Siderastrea siderea }\end{array}$ & $\begin{array}{l}0.60 \pm 0.06 \\
0.68 \pm 0.04 \\
0.66 \pm 0.03\end{array}$ & $\begin{array}{l}0.63 \pm 0.06 \\
0.65 \pm 0.04 \\
0.58 \pm 0.06\end{array}$ & $\begin{array}{r}-0.03 \pm 0.06 \\
0.03 \pm 0.03 \\
0.08 \pm 0.07\end{array}$ & $\begin{array}{l}5 \\
5 \\
8\end{array}$ & $\begin{array}{r}-0.98 \\
2.52 \\
3.21\end{array}$ & $\begin{array}{l}0.50 \\
0.04 \\
0.01\end{array}$ \\
\hline $\begin{array}{l}\text { Asymptotic max. } \\
\left(\mathrm{rETR}_{\max }\right)\end{array}$ & $\begin{array}{l}\text { Montastrea annularis } \\
\text { Porites porites } \\
\text { Siderastrea siderea }\end{array}$ & $\begin{array}{l}107.10 \pm 38.66 \\
116.20 \pm 20.76 \\
136.17 \pm 30.48\end{array}$ & $\begin{array}{r}93.97 \pm 38.55 \\
130.76 \pm 28.92 \\
181.04 \pm 53.82\end{array}$ & $\begin{aligned} 13.13 & \pm 5.97 \\
-14.56 & \pm 17.54 \\
-44.87 & \pm 46.65\end{aligned}$ & $\begin{array}{l}5 \\
5 \\
8\end{array}$ & $\begin{array}{r}4.92 \\
-1.86 \\
-2.72\end{array}$ & $\begin{array}{l}0.01 \\
0.50 \\
0.50\end{array}$ \\
\hline
\end{tabular}
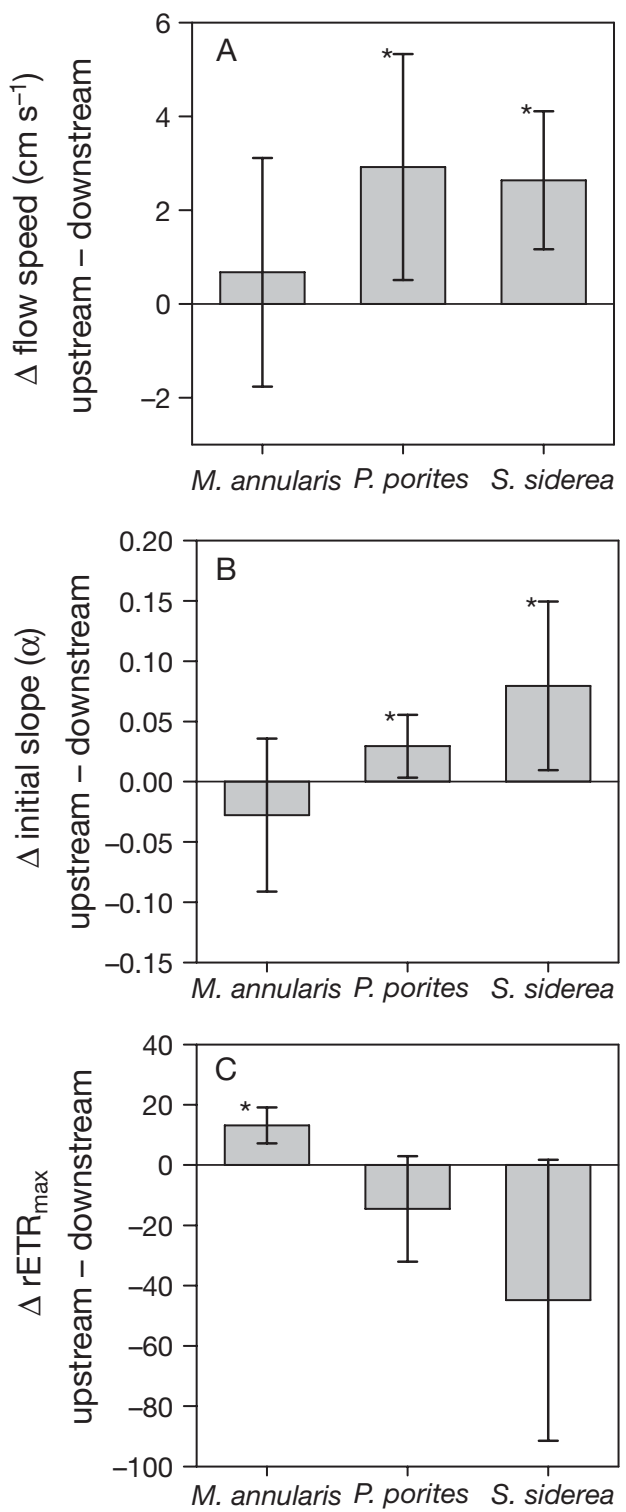

ing) there was more than a 3-fold increase in mean flow speed over the upstream face of the colony relative to the downstream face. For Siderastrea siderea (hemisphere), flow over the upstream face was greater than that over the downstream face by a factor of 2. (Table 1, Fig. 1A). Flow was more uniform over the plate-like colonies of Montastrea annularis (Table 1, Fig. 1A). Species-specific differences in $\alpha$ and $\mathrm{rETR}_{\max }$ were also found. In $P$. porites and $S$. siderea, the initial slopes of the asymptotic RLC $(\alpha)$ were 4 and $12 \%$ higher, respectively, on the upstream faces than on the downstream faces (Table 1, Fig. 1B). In contrast, there was no difference in $\alpha$ between upstream and downstream faces of M. annularis (Table 1, Fig. 1B). The asymptotic maximum $\left(\mathrm{rETR}_{\max }\right)$ was higher on the upstream face of M. annularis than on the downstream face (Table 1, Fig. 1C). In contrast, rETR $_{\max }$ was the same over upstream and downstream faces of $S$. siderea and P. porites (Table 1, Fig. 1C).

Pearson's correlation analyses showed a positive correlation between flow speed and $\alpha$ for Siderastrea siderea. In contrast, there was no relationship between $\mathrm{rETR}_{\max }$ and flow speed for $S$. siderea, nor for flow speed and neither $\alpha$ nor $\mathrm{rETR}_{\max }$ for Porites porites or Montastrea annularis (Table 2).

Fig. 1. Upstream versus downstream differences in flow and photosynthetic activity for 3 experimental species. The mean difference from each paired measurement (upstream - downstream) \pm SD is plotted. In each case, a positive result indicates that upstream measurement $>$ downstream measurement. *Significant difference at $\mathrm{p}<0.05$. (A) Mean difference in flow speed. (B) Mean differences in initial slope $(\alpha)$ of the rapid light curves (RLC) collected on the upstream and downstream faces of the coral. (C) Mean differences in the asymptotic maximum of the RLC $\left(\mathrm{rETR}_{\max }\right) . M$. = Montastrea, $P .=$ Porites, $S .=$ Siderastrea 
Table 2. Results of Pearson's Correlation Analyses testing the null hypothesis of no association between photosynthetic parameters and flow speed. $M .=$ Montastrea, $P .=$ Porites,$S .=$ Siderastrea

\begin{tabular}{|llrcc|}
\hline Parameter & Species & $\mathrm{N}$ & $r$ & $\mathrm{p}$ \\
\hline Initial slope $(\alpha)$ & M. annularis & 8 & 0.21 & 0.61 \\
& P. porites & 8 & 0.25 & 0.55 \\
& S. siderea & 10 & 0.76 & 0.01 \\
Asymptotic max. & M. annularis & 8 & -0.52 & 0.18 \\
(rETR $\left._{\max }\right)$ & P. porites & 8 & -0.01 & 0.99 \\
& S. siderea & 10 & -0.52 & 0.13 \\
\hline
\end{tabular}

On a single occasion we were able to completely characterize the DBL, MBL and RLC on a single head of Siderastrea siderea located on the reef (Fig. 2). The velocity profile over the upstream face of the coral was steeper than over the downstream face (Fig. 2A), indicating faster and more turbulent flow upstream relative to downstream. We estimated the friction (shear) velocity $\left(u_{*}\right.$, a measurement of boundary layer turbulence) using the regression of velocity on the natural logarithm of height above the coral (Vogel 1994). The upstream friction velocity was $2.1 \mathrm{~cm} \mathrm{~s}^{-1}$, whereas the downstream friction velocity was $1.5 \mathrm{~cm} \mathrm{~s}^{-1}$. The thickness of the DBL scales inversely with boundary layer turbulence and we found higher oxygen concentrations over the downstream face of the coral (Fig. 2B). The slope ( $\alpha$ and the asymptote $\left(\mathrm{rETR}_{\max }\right)$ of the RLC were higher on the upstream face of the coral relative to the downstream face (Fig. 2C).

Oxygen profiles revealed high concentrations of oxygen within $2 \mathrm{~mm}$ of the coral surface that gradually declined to ambient concentration with increasing distance from the surface (Fig. 3). Two profiles collected on the upstream side of a single colony of $S$. siderea during 2 different dives (Fig. 3A,B) showed a slight accumulation of oxygen (2 to $15 \%$ above ambient) at heights $<1.0 \mathrm{~mm}$ and a decline to ambient concentration at a height of $1.5 \mathrm{~mm}$. Profiles collected from the center portion of colonies of A. agaricites showed considerable build-up of oxygen ( 20 to $60 \%$ above ambient) within 1 to $2 \mathrm{~mm}$ of the coral surface. In one case (Fig. 3C) the distribution of oxygen over a colony of Agaricia agaricites was similar to that measured over Siderastrea siderea. The oxygen concentration increased at heights $<1.0 \mathrm{~mm}$ and gradually returned to ambient at heights $>1.0 \mathrm{~mm}$. However, in the remaining 2 cases (Fig. 3D,E) the profiles were more complex. In these 2 cases the oxygen concentration was elevated at heights $<1.0 \mathrm{~mm}$ and declined at a height of $1.0 \mathrm{~mm}$. However, there was a secondary rise in concentration at $1.5 \mathrm{~mm}$. Oxygen concentration declined to ambient at $10 \mathrm{~mm}$.

\section{DISCUSSION}

Water flow has wide ranging effects on the ecology and physiology of reef building corals over scales of millimeters to hundreds of meters (Jokiel 1978, Dennison \& Barnes 1988, Atkinson et al. 1994, Lesser et al. 1994, Shashar et al. 1996, Gardella \& Edmunds 2001,
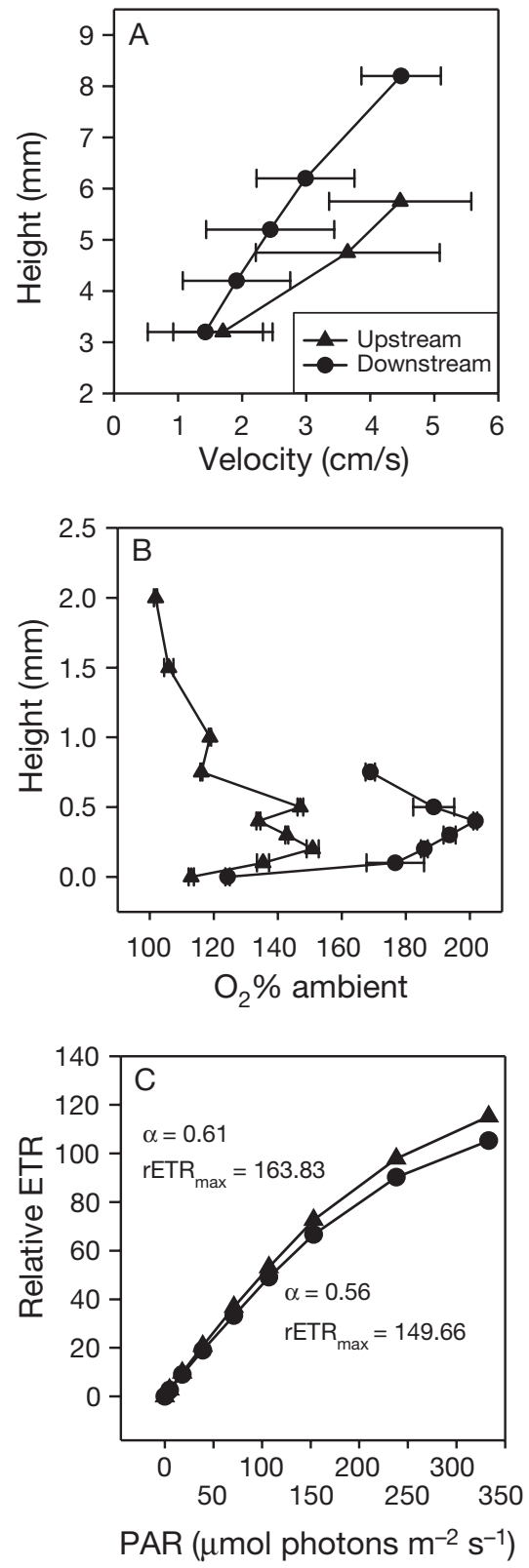

Fig. 2. Siderastrea siderea. Upstream and downstream paired measurements made over a single colony. (A) Flow speed profiles showing faster, more turbulent flow over the upstream face of the coral. (B) Oxygen concentration profiles showing a higher concentration over the downstream face potentially due to reduced boundary layer shear or recirculation. (C) Rapid light curves (RLC) showing higher initial slope $(\alpha)$ of the rETR versus photon irradiance relationship 


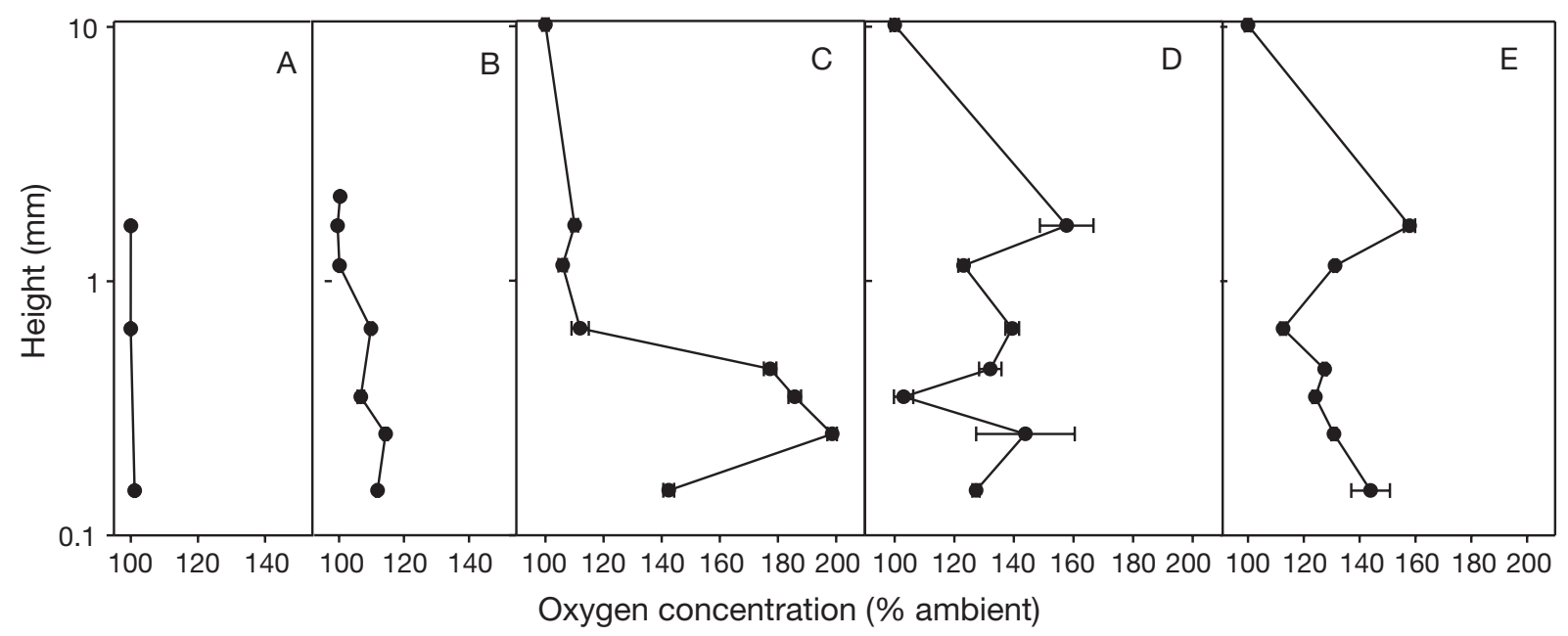

Fig. 3. Oxygen concentration profiles over several colonies of (A,B) Siderastrea siderea and (C,D,E) Agaricia agaricites. Means \pm SD. $100 \%$ represents ambient oxygen concentration

Falter et al. 2004, 2005, Edmunds 2005). Our results suggest that within colony variation in light-limited photosynthetic electron transport (as measured by $\alpha$ ) is more sensitive to flow than light-saturated electron transport rates $\left(\mathrm{rETR}_{\max }\right)$. The initial slope of the RLC $(\alpha)$ was higher on the upstream face (relative to the downstream face) of Siderastrea siderea and Porites porites (Table 1, Fig 1B), the 2 species for which flow was also significantly higher on the upstream face (Table 1, Fig 1A). This suggests that for these 2 species, the portion of the colony facing upstream can more efficiently use incident irradiance during light limited photosynthesis. These results also indicate a strong effect of colony morphology on $\alpha$. Mounding ( $S$. siderea) and cylindrical ( $P$. porites) forms are more likely to experience strong flow gradients than platelike morphologies (Montastrea annularis) (Vogel 1994). Further experimentation with colonies of varying morphology within species is needed to further refine this relationship.

We initially expected both $\alpha$ and $\mathrm{rETR}_{\max }$ to be positively correlated to flow. Those expectations, however, were not borne out by the data, a fact that is potentially explained by our choice of methodology and the processes that control variability in each parameter. The photosynthetic parameters $\alpha$ and rETR $_{\max }$ are generally considered to be independent and controlled by separate processes (see Behrenfeld et al. 2004 for a recent review). Given that each parameter is indicative of processes in separate stages of the photosynthetic mechanism, differential effects of flow on $\alpha$ and $\mathrm{rETR}_{\max }$ are reasonable. Moreover, because $\mathrm{rETR}_{\max }$ is a function of processes 'downstream' of PSII (e.g. enzymatic activity in the Calvin cycle), it may be buffered from the immediate effects of water flow on electron transport rate through PSII (as measured with PAM fluorometry). In contrast, $\alpha$ is a function of the light harvesting capabilities of the photosynthetic reaction centers (Behrenfeld et al. 2004) and varies as a function of processes (especially non-photochemical quenching) that are likely to vary on scales relevant to flow dependence (cm and min) (Müller et al. 2001, Behrenfeld et al. 2004) and can be measured fluorometrically.

Choice of methodology may also explain contrasting results found between our work (this study and Finelli et al. 2006) and Patterson et al. (1991). Patterson et al. (1991), working with small intact hemispherical colonies of Montastrea annularis, used oxygen respirometry to show a positive relationship between maximal photosynthesis and flow at mean velocities between 2.3 and $7.0 \mathrm{~cm} \mathrm{~s}^{-1}$ and light levels between 100 and $600 \mu \mathrm{mol}$ photons $\mathrm{m}^{-2} \mathrm{~s}^{-1}$. They also showed a strong positive effect of flow on dark respiration. In our two studies (this study and Finelli et al. 2006) we found no flow sensitivity in $M$. annularis. Because water flow in their (Patterson et al. 1991) experimental chambers was similar in magnitude to that measured here, we suspect that the conflicting results are due to differences in colony morphology (hemispheres versus flat plates) and methodology (PAM fluorometry versus respirometry). Longstaff et al. (2002) showed that ETR is a valid proxy for oxygen evolution only at low to intermediate irradiances. They suggested that oxygen evolution measurement is the preferred methodology at high light because it accounts for whole organism processes that are not measured fluorometrically. It is possible that the RLC and oxygen evolution measurements will be differently affected by flow because they measure fundamentally different processes. Further experimentation is clearly needed to probe the link 
between fluorometric and oxygen evolution techniques and between flow and photosynthesis.

Methodology does not, however, explain differences in this study and a more recent study (Carpenter \& Patterson 2007). They used PAM fluorometry to show that photosynthetic efficiency of hemispherical colonies of Montastrea annularis was persistently suppressed over an $8 \mathrm{~d}$ period on the upstream face relative to the downstream. In their experiments, flows on the upstream side (range: 20 to $45 \mathrm{~cm} \mathrm{~s}^{-1}$ ) were 5 to 10 times higher than the downstream side (range: 1 to 9 $\mathrm{cm} \mathrm{s}^{-1}$ ). Their results are in direct contrast to our own. They hypothesized that there exists a flow threshold below which flow enhances quantum yield of PSII via enhanced mass transfer (of either $\mathrm{O}_{2}$ out of the coral, or $\mathrm{HCO}_{3}^{-}$in). Above this threshold, however, photosynthesis is downregulated at the cellular level to prevent overstimulation of photosynthetic pathways. Flow speeds measured here and in Finelli et al. (2006) did not reach levels that would surpass such a threshold, and our work is not strictly comparable to that of Carpenter \& Patterson (2007). However, we note that they found strong flow gradients and physiological gradients using hemispherical colonies. In this respect, our work and their work are complementary in suggesting strong interactions between morphology and flow in driving intracolony variation in photosynthesis.

We found that within-colony variation in lightlimited photosynthesis $(\alpha)$ scales positively with flow for mounding and branching colonies. However, our results were mixed at the population level (Table 2). Given that within colony variation in $\mathrm{rETR}_{\max }$ was insensitive to flow in all species, the lack of a significant correlation with flow at the population level is not surprising. However, one might reasonably expect a positive correlation between flow and $\alpha$ for Porites porites and Siderastrea siderea. We did find such a correlation for $S$. siderea, but not for $P$. porites. The results of these correlations suggest that intracolony correlations between flow and $\alpha$ may not readily scale to the population level. Given the spatial heterogeneity in environmental conditions (flow, light, etc.) and the ability of coral polyps and their symbionts to adapt to these conditions, it is possible that flow effects on intracolony variation in photosynthesis will be easier to measure than patterns of intercolony variation. More experimentation is needed to illuminate the links between experiments at the colony level and population level processes.

Within colony variation in photosynthesis can arise from multiple factors, such as variability in symbiotic algal genotype, chlorophyll concentration, or light intensity. We were not able to measure these covariates as part of our study and do not discount their potential importance. In fact, it is critical to determine whether symbiont-related variables (chlorophyll and genotype) vary systematically with flow heterogeneity.

While our current study did not pursue the mechanism by which water flow might enhance photosynthesis, we suspect that efflux of oxygen may play an important role. Our field measurements, although limited in number, showed elevated oxygen concentrations within 1 to $2 \mathrm{~mm}$ of the coral surface. In one case, we were able to demonstrate thicker oxygen boundary layers that corresponded to slower flow and lower $\alpha$ on the downstream face of a colony of Siderastrea siderea relative to its upstream face. These results, coupled with our previous results showing that quantum yield of PSII is reduced in the presence of elevated oxygen and that the effect of oxygen can be modulated by flow (Finelli et al. 2006), support the hypothesis that oxygen accumulation in areas of reduced flow can suppress photosynthesis.

Flow modulation of oxygen transport may also have implications for understanding the patchy distribution of coral bleaching in the field because oxidative stress is known as a direct precursor to bleaching (Lesser 1997, Downs et al. 2002). For example, corals that inhabit sheltered locations, or portions of aggregations which chronically experienced reduced levels of flow, may be more likely to bleach than corals in similar positions subjected to higher flows (Nakamura \& van Woesik 2001). Similarly, in regions of unidirectional flow, some downstream portions of colonies may be more likely to experience bleaching than upstream portions of colonies. Our results suggest that withincolony variations in flow and mass transfer can occur, and may contribute to the patchy nature of coral bleaching within a single coral colony. Importantly, only by understanding the mechanisms of mass transfer and the relationship to photosynthetic performance will we be poised to forecast spatial and temporal patterns in bleaching as they occur over a range of scales on coral reefs.

Acknowledgements. This work was supported by contracts from the National Atmospheric and Oceanic Administration via the National Undersea Research Program administered by the University of North Carolina-Wilmington (NA96RU0260/SEGM-2002-26A). We thank the entire staff at NURC-Key Largo for their absolute and uniform professionalism and expert support. We also acknowledge the help of M. Mills, K. Fedorka, M. O'Donnell, C. Dryden, H. Bush, and K. Castillo whose countless hours in the water made this research possible.

\section{LITERATURE CITED}

Aronson RB, Edmunds PJ, Precht WF, Swanson DW, Levitan DR (1994) Large-scale, long-term monitoring of Caribbean coral reefs: simple, quick, inexpensive techniques. Atoll Res Bull 421:1-19 
Asada K (1999) The water cycle in chloroplasts: scavenging of active oxygens and dissipation of excess photons. Annu Rev Plant Physiol Mol Biol 50:601-639

Atkinson MJ, Bilger R (1992) Effects of water velocity on phosphate uptake in coral reef-flat communities. Limnol Oceanogr 37:273-279

Atkinson MJ, Kotler E, Newton P (1994) Effects of water velocity on respiration, calcification, and ammonium uptake of a Porites compressa community. Pac Sci 48: 296-303

Behrenfeld MJ, Prasil O, Babin M, Bruyant F (2004) In search of a physiological basis for covariations in light-limited and light-saturated photosynthesis. J Phycol 40:4-25

Carpenter LW, Patterson MR (2007) Water flow influences the distribution of photosynthetic efficiency within the scleractinian Montastrea annularis (Ellis and Solander, 1786). Can water flow modulate coral reef bleaching? J Exp Mar Biol Ecol 351:10-26

Dennison WC, Barnes DJ (1988) Effect of water motion on coral photosynthesis and calcification. J Exp Mar Biol Ecol 115:67-77

Downs CA, Fauth JE, Halas JC, Dustan P, Bemiss J, Woodley CM (2002) Oxidative stress and seasonal coral bleaching. Free Radical Biol Med 33:533-543

Edmunds PJ (2005) Effect of elevated temperature on aerobic respiration of coral recruits. Mar Biol 146:655-663

Falter JL, Atkinson MJ, Merrifield MA (2004) Mass-transfer limitation of nutrient uptake by a wave-dominated reef flat community. Limnol Oceanogr 49:1820-1831

Falter JL, Atkinson MJ, Coimbra CFM (2005) Effects of surface roughness and oscillatory flow on the dissolution of plaster forms: evidence for nutrient mass transer to coral reef communities. Limnol Oceanogr 50:246-254

Finelli CM (2000) Velocity and concentration distributions in turbulent odor plumes in the presence of vegetation mimics: a flume study. Mar Ecol Prog Ser 207:297-309

Finelli CM, Helmuth BST, Pentcheff ND, Wethey DS (2006) Water flow controls oxygen transport and photosynthesis in corals: potential links to coral bleaching. Coral Reefs 25: 47-57

Gardella DJ, Edmunds PJ (1999) The oxygen microenvironment adjacent to the tissue of the scleractinian Dichocoenia stokesii and its effects on symbiont metabolism. Mar Biol 135:289-295

Gardella DJ, Edmunds PJ (2001) The effect of flow and morphology on boundary layers in the scleractinians Dichocoenia stokesii (Milne-Edwards and Haime) and Stephanocoenia michilini (Milne-Edwards and Haime). J Exp Mar Biol Ecol 256:279-289

Jokiel PL (1978) Effects of water motion on reef corals. J Exp Mar Biol Ecol 35:87-97

LaBarbera M, Vogel S (1976) An inexpensive thermistor flowmeter for aquatic biology. Limnol Oceanogr 21: 750-756

Leichter JJ, Stewart HL, Miller SL (2003) Episodic nutrient

Editorial responsibility: Charles Birkeland (Contributing Editor), Honolulu, Hawaii, USA transport to Florida coral reefs. Limnol Oceanogr 48: 1394-1407

Lesser MP (1996) Elevated temperatures and ultraviolet radiation cause oxidative stress and inhibit photosynthesis in symbiotic dinoflagellates. Limnol Oceanogr 41:271-283

Lesser MP (1997) Oxidative stress causes coral bleaching during exposure to elevated temperatures. Coral Reefs 16: 187-192

Lesser MP (2006) Oxidative stress in marine environments: biochemistry and physiological ecology. Annu Rev Physiol 68:253-278

Lesser MP, Weis VM, Patterson MR, Jokiel PL (1994) Effects of morphology and water motion on carbon delivery and productivity in the reef coral, Pocillopora damicornis (Linnaeus): diffusion barriers, inorganic carbon limitation, and biochemical plasticity. J Exp Mar Biol Ecol 178:153-179

Longstaff BJ, Kildea T, Runcie JW, Chesire A, Dennison WC, Hurd C, Kana T, Raven JA, Larkum AWD (2002) An in situ study of photosynthetic oxygen exchange and electron transport rate in the marine macroalga Ulva lactuca (Chlorophyta). Photosynth Res 74:281-293

Müller P, Li XP, Niyogi KK (2001) Non-photochemical quenching. A response to excess light energy. Plant Physiol 125:1558-1566

Nakamura T, van Woesik R (2001) Water-flow rates and passive diffusion partially explain differential survival of corals during the 1998 bleaching event. Mar Ecol Prog Ser 212:301-304

Nakamura T, Yamasaki H, van Woesik R (2003) Water flow facilitates recovery from bleaching in the coral Stylophora pistillata. Mar Ecol Prog Ser 256:287-291

Patterson MR, Sebens KP, Olson RR (1991) In situ measurements of flow effects on primary production and dark respiration in reef corals. Limnol Oceanogr 36:936-948

Platt T, Gallegos CL, Harrison WG (1980) Photoinhibition of photosynthesis in natural assemblages of marine phytoplankton. J Mar Res 38:687-701

Ralph PJ, Gademann R, Larkum AWD, Kuhl M (2002) Spatial heterogeneity in active chlorophyll fluorescence and PSII activity in coral tissues. Mar Biol 141:639-646

Shashar N, Kinane S, Jokiel PL, Patterson MR (1996) Hydromechanical boundary layers over a coral reef. J Exp Mar Biol Ecol 199:17-28

Tchernov D, Gorbunov MY, de Vargas C, Yadav SN, Milligan AJ, Haggblom M, Falkowski PG (2004) Membrane lipids of symbiotic algae are diagnostic of sensitivity to thermal bleaching in corals. Proc Nat Acad Sci USA 101: 13531-13535

Thomas FIM, Atkinson MJ (1997) Ammonium uptake by coral reefs: effects of water velocity and surface roughness on mass transfer. Limnol Oceanogr 42:81-88

Vogel S (1994) Life in Moving Fluids. Princeton University Press, Princeton, NJ

Zar JH (1984) Biostatistical Analysis. Prentice Hall, Englewood Cliffs, NJ

Submitted: October 13, 2006; Accepted: May 25, 2007

Proofs received from author(s): October 25, 2007 